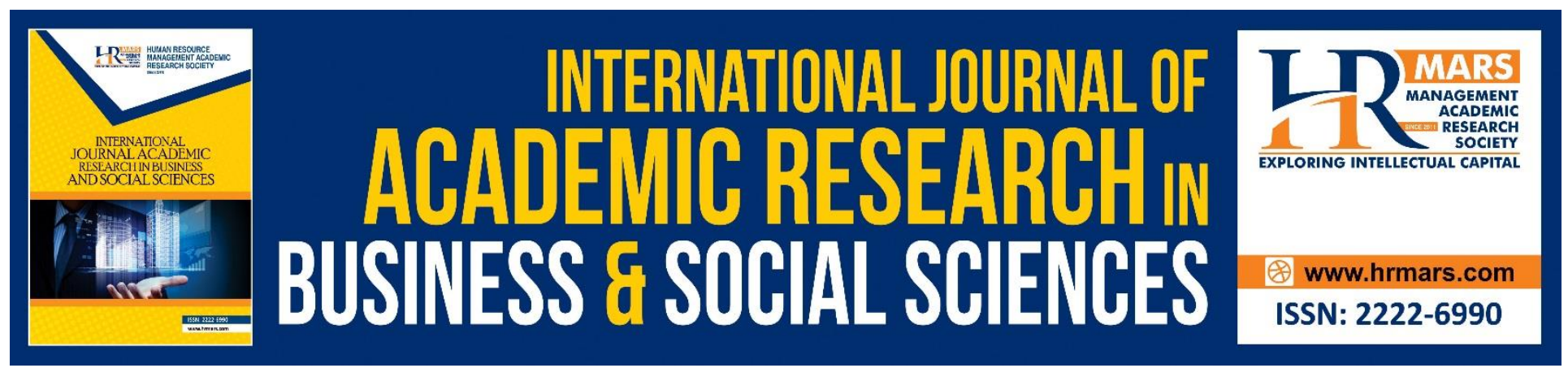

\title{
The Contribution of Various Sectors in West Malaysia to the Economic Growth: An Input-Output Analysis
}

Mohd Khairul Hisyam Hassan, Zaleha Mohd Noor, Normaz Wana Ismail, Alias Radam, Zakariah Abdul Rashid

To Link this Article: http://dx.doi.org/10.6007/IJARBSS/v9-i1/5391

DOI: $\quad 10.6007 /$ IJARBSS/v9-i1/5391

Received: 21 Dec 2018, Revised: 26 Jan 2019, Accepted: 29 Jan 2019

Published Online: 06 Feb 2019

In-Text Citation: (Hassan, Noor, Ismail, Radam, \& Rashid, 2019)

To Cite this Article: Hassan, M. K. H., Noor, Z. M., Ismail, N. W., Radam, A., \& Rashid, Z. A. (2019). The Contribution of Various Sectors in West Malaysia to the Economic Growth: An Input-Output Analysis. International Journal of Academic Research in Business and Social Sciences, 9(1), 221-234.

Copyright: (C) 2019 The Author(s)

Published by Human Resource Management Academic Research Society (www.hrmars.com)

This article is published under the Creative Commons Attribution (CC BY 4.0) license. Anyone may reproduce, distribute, translate and create derivative works of this article (for both commercial and non-commercial purposes), subject to full attribution to the original publication and authors. The full terms of this license may be seen

at: http://creativecommons.org/licences/by/4.0/legalcode

Vol. 9, No. 1, 2019, Pg. 221 - 234

http://hrmars.com/index.php/pages/detail/IJARBSS

JOURNAL HOMEPAGE

Full Terms \& Conditions of access and use can be found at http://hrmars.com/index.php/pages/detail/publication-ethics 


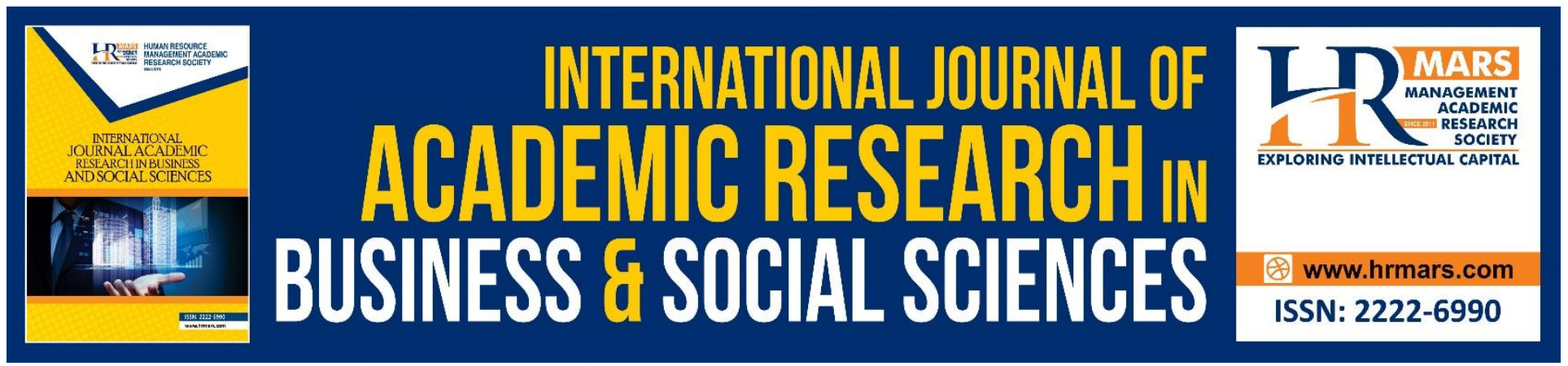

\title{
The Contribution of Various Sectors in West Malaysia to the Economic Growth: An Input-Output Analysis
}

\author{
Mohd Khairul Hisyam Hassan \\ Department of Economics, Faculty of Economics and Business, Universiti Malaysia Sarawak \\ Malaysia \\ Zaleha Mohd Noor \\ Department of Economics, Faculty of Economics and Management, Universiti Putra Malaysia \\ Malaysia
}

Normaz Wana Ismail

Department of Economics, Faculty of Economics and Management, Universiti Putra Malaysia Malaysia

\section{Alias Radam}

Department of Management, Faculty of Economics and Management, Universiti Putra Malaysia Malaysia

\section{Zakariah Abdul Rashid}

Malaysian Institute of Economic Research, JKR 606, Jalan Bukit Petaling, P.O. Box 12160, Kuala Lumpur Malaysia

\begin{abstract}
By using the regional input-output approach, this paper attempts to analyse the contribution of the various sectors in West Malaysia to economic growth as well as the regional development planning. Our linkage effects strongly suggest that there is a strong argument to believe that a further developed West Malaysia with greater facilities and investment for the petroleum products; other manufacturing; and wholesale and retail trade sectors will make it an increasingly sources of growth in the West Malaysia. Moreover, the empirical results also reveal that petroleum products; electronics and non-electronics; motor vehicles and other transport; and other manufacturing; were among the sectors with high multiplier values in West Malaysia compared to other sectors.
\end{abstract}


INTERNATIONAL JOURNAL OF ACADEMIC RESEARCH IN BUSINESS AND SOCIAL SCIENCES

Vol. 9, No. 1, Jan, 2019, E-ISSN: $2222-6990$ (C) 2019 HRMARS

Keywords: West Malaysia; Economic Growth; Input-Output Analysis; Multipliers; Linkages

\section{INTRODUCTION}

Malaysia introduced regional economic growth corridors during the Ninth Malaysia Plan with five regional cities and economic corridors, namely Georgetown and the Northern Corridor Economic Region (NCER); Johor Bahru and Iskandar Malaysia (IM); Kuantan and East Coast Economic Region (ECER); Kuching and Sarawak Corridor of Renewable Energy (SCORE); and Kota Kinabalu and Sabah Development Corridor (SDC). The focus of regional development was on increasing the standard of living and achieving balanced socio-economic development across regions and states. One of the objectives of these initiatives was to transform Malaysia into a high-income nation by 2020. Expansion of economic growth contributes significantly to the development of the country, but it also contributes to a widening of the differences between the regions and states in terms of income, employment and GDP per capita. This situation happens because most of the industrial and commercial economic activities tend to concentrate in certain regions and are not evenly distributed across the regions and states. Thus, in planning economic growth for West Malaysia, policymakers should obtain detailed information on the potentials and opportunities in each economic sector that should be emphasized. In addition, to select the potentials of a sector, policymakers must also know the existing interindustry linkages so that any steps to develop the economy can be distributed to the whole industry. Since information at sectoral level is important in regional economic planning, every country should have regional input-output table. Moreover, West Malaysia non-resource-based (manufacturing) sectors to drive the Malaysian economy during the last decade. So, by developing the regional input-output table, this study could contribute to the economic planning for West Malaysia region. Thus, the purpose of the study is to construct regional IO table for West Malaysia region for the year 2005. This paper consists of five sections. Section 2 presents the literature review on theoretical and empirical studies. Section 3 discusses the data and methodology that is used in the empirical analysis. Section 4 presents a discussion of the results followed by the conclusion in Section 5.

\section{LITERATURE REVIEW}

In the construction of regional input-output table, the accuracy of the coefficients estimated is very important via use of survey-based method, non-survey based method and hybrid model. It is because of the reliability of the regional input-output table needed to reflect the real situation in a particular region or economy. The concept of accuracy in regional input-output tables was first studied by Jensen (1980). He introduced a partitive holistic framework in the context of input-output tables and found that this framework is best for conceptualizing the accuracy problem. Based on his findings, the implication behind the accuracy concept of regional input-output table was the identification of the most significant social and economic elements. This, however is hard to justify in ignoring the insignificant elements. So, holistic accuracy is the best solution in solving this problem. Basically, regional input-output table is similar to national input-output table which is based on the inputoutput table developed by Wassily Leontief, who was inspired by François Quesnay's concept of the Tableau Economique. The concept of input-output framework consists of a number of different sectors in the economy, where each of the sectors requires resources from the other sectors to 
produce some output. The transactions between or within sectors in the economy can be seen in an interindustry transactions matrix (Richardson, 1972). The construction of a regional input-output table using survey-based method needs data from survey to calculate the supply and use tables, and later to derive a regional input-output table. This is basically the method to develop a national inputoutput table. However, to construct a regional input-output table, there is a need for some modification to be made for the different information of a certain account. Since conducting a survey with the necessary details is extremely expensive, the pure survey-based method is rarely used nowadays. Instead, non-survey based method and hybrid model have become popular. A non-survey based method uses the national table to produce a regional table. The modification of the national table uses the indicators for a region where it is a contribution of the total industry aggregates. Facing a trade-off between the costly pure survey method on the one hand and the limited accuracy of the pure non-survey based method on the other, input-output analysts have been attracted by mixture between the two, which has become known as the hybrid model.

As the regional planning and development for a particular region are more important to policymakers in providing appropriate policy recommendations, Hewings and Jensen (1988) noted the new interest and focus on the field of regional input-output tables which is more challenging, interesting, and exciting than the traditional approach in analysing the regional input-output analysis. Their focus was characterized as (1) the conceptualization of input-output within the traditions of econometric analysis; (2) the integration of input-output with other regional and inter-regional models, and (3) attempts to link input-output analysis with regional growth and development theory. Jensen et al. (1988) also studied the structure of national and regional economic structures using the conventional input-output data in their analysis based on ten regions of Queensland as a sample in order to make some appropriate policy recommendations for the regions. Using a different method and different data (survey data), Emerson (1989) employed two sets of survey data from regional input-output models to analyse the structural changes in regional economy. Significant structural changes were observed in the economic structure over the period of 20 years. But several sectors recorded small changes in their sectors. Bolton et al. (1990) listed the literature on the various issues in regional input-output analysis that included movement survey-based methods and alternative methods such as non-survey-based methods and hybrid model. Besides that, they also mentioned the extended model in the regional model such as demographic and socio-elements, and lastly the integrated model which is a combination of econometric and regional economic models. Brucker et al. (1990) compared the use of semi-survey-based data for five models to estimate the impact of economic changes on a region. Applying the recent method in constructing the regional input-output table, Flegg and Tohmo (2010) conducted a study in regional input-output tables and the FLQ formula: a case study of Finland. They used data for 20 Finnish regions, ranging in size from very small to very large for 1995, and identified 37 separate sectors. In addition, this study focused on the LQ-based method (including FLQ, SLQ, CILQ and AFLQ). The finding showed that differences between regional and national ratios of intermediate to primary inputs were of much fewer concerns. Moreover, the AFLQ was found to be very similar indeed to the FLQ in terms of both accuracy and pattern of errors. The finding is very helpful to any regional analyst who is contemplating making use of the FLQ formula 
to generate initial sets of regional input-output coefficients. Furthermore, these coefficients could be used either as part of the RAS procedure or as the non-survey foundation of a hybrid model.

Recently, Flegg and Tohmo (2018) used South Korea national input coefficient of 2005 national table to generate the regional coefficient based on FLQ and also to investigate the sectoral output multiplier. Before making any adjustment for interregional trade, the supplying sectors and the regional purchasing size must be taken in to consider in order solving the cross hauling problem cause by export and imports of commodity. Based on FLQ concept the smaller the region the more accurate of results and are more open to the interregional trade. This research comparing the results of CILQ, SLQ and FLQ, thus the results perform by FLQ is outperform than others and known as one of the best regionalization method. CLIQ and SLQ generate overestimate multiplier showing bias on the size which are proved by Theil's inequality index that consider depression and bias in account. However, FLQ can just only be relied to provide acceptable primary set of the input coefficient at regional level.

\section{METHODOLOGY AND DATA}

In this study, the construction of regional input-output table for West Malaysia used the non-survey method. The main sources of data were taken from the Department of Statistics, Malaysia, for the development of the regional input-output table with the national input-output table used as a reference.

\section{RAS Technique}

The RAS method is originally developed by Professor Stone in 1961, at the moment RAS method are one of the famous non-survey based method used in input-output study in the regional science field to estimate the regional input-output coefficient. RAS method is one of the best modification methods to adjust the basic matrix, in order to stabilize and enhance the matrix over the system. In this study, Hassan, et al. (2017) RAS model is applied to estimate the coefficient. This method can be explained by the following equation:

$$
A^{*}=R A S
$$

where $A$ is direct input-output coefficient matrix at national level, $R$ and $S$ are diagonal matrices of row and column constraints, and $A^{*}$ is an estimated direct input-output coefficient at state level. Matrix $A$ of state direct coefficient matrix in equation (1) is formed as a result of pre-and postmultiplication of a matrix with a diagonal matrix.

This implies that each element $a^{*}{ }_{i j}$ matrix $A^{*}$ obtained from any element $a_{i j}$ matrix $A$ as the following equation:

$$
a^{*}{ }_{i j}=r_{i} a_{i j} s_{j}
$$

Since equation (2) shows all the elements of the matrices $A$ and $A^{*}$ are the same, then the dimensions of the two matrices are also similar. Each element of $R$ must be equal to the number of lines $A$ and $A^{*}$, while the number of columns $A$ and $A^{*}$ determine the number of elements of $S$. In each row of 
the RAS technique, elements $R$ and $a^{*}{ }_{i j}$ are formed by multiplying each element of row $i$ matrix $A$ by the same $R$ factor. When all operating lines for matrix $A$ are finished, they will produce a matrix $W$ :

$$
W=R A
$$

or equivalent:

$$
w_{i j}=r_{i} a_{i j}
$$

The last process to form the matrix ${ }_{1} A$ is multiplying every element $j$ column of the matrix $W$ by each element of column $j$ factor $S$. This will produce a matrix $W S$,

$$
W S=R \quad A \quad S=A^{*}
$$

where,

$$
a^{*}{ }_{i j}=z_{i j} S_{j}=r_{i} a_{i j} s_{j}
$$

\section{The Rasmussen Unweighted Approach}

In Rasmussen (1956) termed the backward indices as the power of dispersion index. Coefficient of dispersion shows the dependence of a particular sector on other sectors in a regional economy. The power of dispersion index is defined as:

$$
U_{j}=\frac{\frac{1}{n} b_{j_{\bullet}}}{\frac{1}{n^{2}} \sum_{j=1}^{n} b_{j}}
$$

Secondly, this is also known as sensitivity of dispersion that shows forward linkage or support from a particular sector to other sectors. The sensitivity of dispersion index is defined as

$$
U_{i}=\frac{\frac{1}{n} b_{i}}{\frac{1}{n^{2}} \sum_{i=1}^{n} b_{i}}
$$

\section{The Rasmussen Weighted Approach}

The weights for backward linkages are the shares of sectors in final demand components and weights for forward linkages are the primary in put components (value added). Basically, the measurement of weighted average is to take into account the importance of each sector in terms of final demand and primary inputs. 
INTERNATIONAL JOURNAL OF ACADEMIC RESEARCH IN BUSINESS AND SOCIAL SCIENCES

Vol. 9, No. 1, Jan, 2019, E-ISSN: 2222-6990 C 2019 HRMARS

Using the normalizing approach, the weighted backward and forward indices are given as:

and

$$
U_{j}^{w}=\frac{\frac{1}{n} b_{j^{*}}^{w}}{\frac{1}{n^{2}} \sum_{j=1}^{n} b_{j^{*}}^{w}}
$$

$$
U_{i}^{w}=\frac{\frac{1}{n} b_{i^{*}}^{w}}{\frac{1}{n^{2}} \sum_{i=1}^{n} b_{i^{*}}^{w}}
$$

\section{Output Multipliers}

The measurement of value for simple output multiplier of a sector is given by the formula;

$$
T O_{j}=\sum_{i=1}^{n} z_{i j}
$$

where $T O_{j}$ is a simple output multiplier for sector $j$ and $z_{i j}$ is an element in the Leontief inverse matrix (regional).

\section{Primary Input Multipliers}

The primary input multipliers are obtained by using the following equation:

$$
T P_{j}=\sum_{i=1}^{n} x_{i} z_{i j}
$$

where $T P_{j}$ is a simple primary input multiplier for sector $j, z_{i j}$ is an element in the Leontief inverse matrix (regional) and $x_{i}$ is a share of primary input components (value-added, import and taxes) for sector $i$.

\section{Employment Multipliers}

The measurement for the employment multiplier is shown as follows:

$$
T E_{j}=\sum_{i=1}^{n} E_{n+1, i} z_{i j}
$$

where $T E_{j}$ is a simple employment multiplier sector $j, E_{n+1}, i$ is a employment coefficient sector $i$ and $z_{i j}$ is an element in the Leontief inverse matrix (regional). 
INTERNATIONAL JOURNAL OF ACADEMIC RESEARCH IN BUSINESS AND SOCIAL SCIENCES

Vol. 9, No. 1, Jan, 2019, E-ISSN: 2222-6990 C 2019 HRMARS

\section{Data}

The dataset in this study includes mainly two categories. The first set of data is on regional inputoutput particularly for final demand and primary input side, which enables one to explore the flows of goods and services between producers and consumers and inter-relationships between all economic sectors in a region. The second set of data used Malaysia's input-output table for 2005 published by the Department of Statistics, Malaysia and perhaps gives the most accurate information about the interindustry relations and structure of the economy.

\section{EMPIRICAL RESULTS}

West Malaysia recorded a total output of RM1,396,475 million in year 2005 and manufacturing appeared to be the most important activity in terms of output generation with value of RM721,649 million. The electronics and non-electronics sector was the main sector with value of RM346,073 million and represented nearly half of the overall total output under the overall manufacturing sector. It was followed by other manufacturing (18.2 per cent), petroleum products ( 9.8 per cent) and food manufacturing ( 9.7 per cent) sectors. Finance, insurance, real estate, and business services; and wholesale and retail trade; were ranked the second and third most important sectors in West Malaysia with values of RM194,332 million (13.9 per cent) and RM160,198 million (11.5 per cent) respectively. Fisheries, sawmill products, and forestry and logging emerged as the least important output generating sectors (Table 1).

Table 1 Contribution of Each Sector to the Gross Outputs in West Malaysia, 2005

\begin{tabular}{lcc} 
& West Malaysia \\
Sector & Percentage \\
& RM million & $(\%)$ \\
\cline { 2 - 3 } & & 1.4 \\
\hline Agriculture and livestock & 18,969 & 0.2 \\
Forestry and logging & 2,153 & 0.3 \\
Fisheries & 4,671 & 2.9 \\
Mining and quarrying & 40,775 & 5.0 \\
Food manufacturing & 70,225 & 0.3 \\
Sawmill products & 4,765 & 1.4 \\
Furniture and fixtures & 20,208 & 3.2 \\
Chemicals products & 44,755 & 5.0 \\
Petroleum products & 70,369 & 24.8 \\
Electronics and non-electronics & 346,073 & 2.4 \\
Motor vehicles and other transport & 33,905 & 9.4 \\
Other manufacturing & 131,349 & 1.8 \\
Electricity, gas and water & 25,727 & 4.0 \\
Construction & 55,340 & 11.5 \\
Wholesale and retail trade & 160,198 & 1.8 \\
Hotels and restaurants & 24,699 & 5.6 \\
Transport, storage and communication & 78,125 & 13.9 \\
Finance, insurance, real estate and business services & 194,332 & 0.8 \\
Other services & 10,524 & 4.2 \\
Government services & 59,314 & 100.0 \\
\hline Total & $1,396,475$ & \\
\hline Source: Input-output table of West & & \\
\hline
\end{tabular}

Source: Input-output table of West Malaysia, 2005 
INTERNATIONAL JOURNAL OF ACADEMIC RESEARCH IN BUSINESS AND SOCIAL SCIENCES Vol. 9, No. 1, Jan, 2019, E-ISSN: $2222-6990$ (c) 2019 HRMARS

By using the unweighted approach for the single-region input-output model, West Malaysia recorded six key sectors, i.e. petroleum products; other manufacturing; electricity, gas and water; transport, storage and communication; finance, insurance, real estate and business services; and other services sectors.

Table 2 Backward and Forward Linkages in West Malaysia (Rasmussen Unweighted Approach), 2005

\begin{tabular}{lcccc}
\hline & \multicolumn{4}{c}{ West Malaysia } \\
\cline { 2 - 5 } Sector & \multicolumn{3}{c}{ Backward linkages } & Forward linkages \\
\cline { 2 - 5 } & Index & Rank & Index & Rank \\
\hline Agriculture and livestock & 0.6560 & 19 & 1.3530 & 3 \\
Forestry and logging & 0.6565 & 18 & 1.6195 & 1 \\
Fisheries & 0.9425 & 14 & 0.6866 & 17 \\
Mining and quarrying & 0.5769 & 20 & 1.5679 & 2 \\
Food manufacturing & 1.2902 & 1 & 0.8577 & 13 \\
Sawmill products & 0.9079 & 16 & 0.8256 & 14 \\
Furniture and fixtures & 1.0699 & 10 & 0.9654 & 11 \\
Chemicals products & 1.1015 & 7 & 0.7464 & 16 \\
Petroleum products & 1.1271 & 5 & 1.2589 & 5 \\
Electronics and non-electronics & 0.9397 & 15 & 0.6747 & 18 \\
Motor vehicles and otheryyyyyy transport & 1.0946 & 8 & 0.5354 & 20 \\
Other manufacturing & 1.0916 & 9 & 1.0348 & 10 \\
Electricity, gas and water & 1.1028 & 6 & 1.0804 & 8 \\
Construction & 1.0345 & 11 & 0.8595 & 12 \\
Wholesale and retail trade & 0.8708 & 17 & 1.1207 & 6 \\
Hotels and restaurants & 1.2097 & 2 & 0.8149 & 15 \\
Transport, storage and communication & 1.1874 & 3 & 1.2622 & 4 \\
Finance, insurance, real estate and business services & 1.0209 & 12 & 1.0371 & 9 \\
Other services & 1.1507 & 4 & 1.1037 & 7 \\
Government services & 0.9688 & 13 & 0.5956 & 19 \\
\hline Source: Input-output table of & & & &
\end{tabular}

Source: Input-output table of West Malaysia, 2005

On the other hand, Table 3 gives the weighted approach coefficients for West Malaysia region. In West Malaysia, four main sectors recorded values of backward and forward linkages of more than 1 (key sectors), which were electronics and non-electronics; other manufacturing; wholesale and retail trade; and finance, insurance, real estate and business services. 
INTERNATIONAL JOURNAL OF ACADEMIC RESEARCH IN BUSINESS AND SOCIAL SCIENCES Vol. 9, No. 1, Jan, 2019, E-ISSN: 2222-6990 @ 2019 HRMARS

Table 3 Backward and Forward Linkages in West Malaysia (Rasmussen Weighted Approach), 2005

\begin{tabular}{lcccc}
\hline & \multicolumn{4}{c}{ West Malaysia } \\
\cline { 2 - 5 } Sector & Backward linkages & Forward linkages \\
\cline { 2 - 5 } & Index & Rank & Index & Rank \\
\hline Agriculture and livestock & 0.1417 & 18 & 0.9224 & 7 \\
Forestry and logging & 0.1054 & 19 & 0.0859 & 18 \\
Fisheries & 0.4226 & 16 & 0.0755 & 19 \\
Mining and quarrying & 0.1003 & 20 & 2.5719 & 3 \\
Food manufacturing & 1.1644 & 6 & 0.3941 & 11 \\
Sawmill products & 0.2485 & 17 & 0.0534 & 20 \\
Furniture and fixtures & 0.5728 & 14 & 0.2648 & 14 \\
Chemicals products & 0.9243 & 10 & 0.2830 & 13 \\
Petroleum products & 0.5905 & 12 & 0.2438 & 15 \\
Electronics and non-electronics & 4.5297 & 1 & 1.6473 & 4 \\
Motor vehicles and other transport & 1.5373 & 3 & 0.0933 & 17 \\
Other manufacturing & 1.3567 & 4 & 1.4270 & 6 \\
Electricity, gas and water & 0.4891 & 15 & 0.5020 & 10 \\
Construction & 1.1388 & 7 & 0.5739 & 9 \\
Wholesale and retail trade & 1.1244 & 8 & 3.5801 & 2 \\
Hotels and restaurants & 0.8507 & 11 & 0.3615 & 12 \\
Transport, storage and communication & 0.9936 & 9 & 1.5339 & 5 \\
Finance, insurance, real estate and business services & 1.8921 & 2 & 4.4478 & 1 \\
Other services & 0.5822 & 13 & 0.1674 & 16 \\
Government services & 1.2348 & 5 & 0.7709 & 8 \\
\hline SOurce: Input-output table & & & &
\end{tabular}

Source: Input-output table of West Malaysia, 2005

By using the single-region input-output model, the food manufacturing sector had the largest output multiplier in West Malaysia. This means that increasing a unit of the final demand would increase the output multipliers of the food manufacturing sector 2.3213 units. This value of output generated in the West Malaysia economy included direct effects and indirect effects. The hotels and restaurants sector with value of 2.1765 was the next largest output multiplier sector behind the food manufacturing sector in West Malaysia, followed by the transport, storage and communication sector with value of 2.1363. For the primary input multipliers in West Malaysia, the highest import multiplier (foreign and inter-regional import) was found for the electronics and non-electronics sector with the multiplier coefficient of 0.6351 , showing this sector's strong capability and potential for import. Among others, the motor vehicles and other transport sector recorded import multiplier (foreign and inter-regional import) of 0.4883 , chemical products 0.4665 , other manufacturing 0.4530 , construction 0.4305 , and sawmill products 0.3852 . 
For the value added, the mining and quarrying sector recorded the highest value added multiplier in West Malaysia with value of 0.8893 . This shows that any increase in the final demand of these sectors would lead to a big generation of value added in the West Malaysia region. The agriculture and livestock sector had the next most important value added multiplier in West Malaysia with value of 0.8574 , followed by the hotels and restaurants sector with multiplier coefficient of 0.8538 . For domestic taxes multipliers, the motor vehicles and other transport sector recorded the highest value West Malaysia with coefficient of 0.1024 , while the forestry and logging sector recorded the highest import taxes multiplier for West Malaysia with value of 0.2453 . This indicates that these sectors were among the main contributors to the government revenue from the West Malaysia region through indirect taxes in 2005.

The agriculture and livestock sector gave the highest employment multiplier in West Malaysia with value of 0.0522 . So, increasing a unit of final demand in this sector would increase 0.0522 unit of employment in the West Malaysia region. In West Malaysia, several important sectors contributed to the employment. The other services sector was ranked second with value of 0.0475 , followed by the hotels and restaurants (0.0339), government services (0.0247), food manufacturing (0.0204), fisheries (0.0202) and construction (0.0171) sectors. The forestry and logging, and mining and quarrying sectors emerged as the smallest contributors to the employment multipliers with values of 0.0027 and 0.0008 respectively. 
INTERNATIONAL JOURNAL OF ACADEMIC RESEARCH IN BUSINESS AND SOCIAL SCIENCES

Vol. 9, No. 1, Jan, 2019, E-ISSN: 2222-6990 @ 2019 HRMARS

Table 4 Output, Value-Added, Import, Domestic Tax, Import Duties, and Employment Multipliers in West Malaysia, 2005

\begin{tabular}{|c|c|c|c|c|c|c|c|}
\hline \multirow{3}{*}{ Sector } & \multicolumn{7}{|c|}{ West Malaysia } \\
\hline & \multirow[b]{2}{*}{ Output } & \multirow[b]{2}{*}{$\begin{array}{l}\text { Value- } \\
\text { added }\end{array}$} & \multicolumn{2}{|c|}{ Import } & \multirow[b]{2}{*}{$\begin{array}{l}\text { Domestic } \\
\operatorname{tax}\end{array}$} & \multirow[b]{2}{*}{$\begin{array}{l}\text { Import } \\
\text { duties }\end{array}$} & \multirow[b]{2}{*}{ Emp* } \\
\hline & & & Foreign & $\begin{array}{l}\text { Inter- } \\
\text { regional }\end{array}$ & & & \\
\hline Agriculture and livestock & 1.1802 & 0.8574 & 0.1275 & 0.0146 & 0.0008 & 0.0011 & 0.0522 \\
\hline Forestry and logging & 1.1811 & 0.6105 & 0.0703 & 0.0755 & 0.0208 & 0.2453 & 0.0027 \\
\hline Fisheries & 1.6958 & 0.7667 & 0.1939 & 0.0317 & 0.0104 & 0.0012 & 0.0202 \\
\hline Mining and quarrying & 1.0380 & 0.8893 & 0.1083 & 0.0009 & 0.0015 & 0.0001 & 0.0008 \\
\hline Food manufacturing & 2.3213 & 0.6490 & 0.3246 & 0.0198 & 0.0063 & 0.0025 & 0.0204 \\
\hline Sawmill products & 1.6335 & 0.5619 & 0.3361 & 0.0491 & 0.0103 & 0.0517 & 0.0057 \\
\hline Furniture and fixtures & 1.9250 & 0.6117 & 0.3636 & 0.0084 & 0.0056 & 0.0123 & 0.0096 \\
\hline Chemicals products & 1.9818 & 0.5223 & 0.4438 & 0.0227 & 0.0086 & 0.0062 & 0.0065 \\
\hline Petroleum products & 2.0279 & 0.6586 & 0.2889 & 0.0488 & 0.0039 & 0.0095 & 0.0042 \\
\hline Electronics and non-electronics & 1.6906 & 0.3615 & 0.6286 & 0.0065 & 0.0027 & 0.0018 & 0.0062 \\
\hline Motor vehicles and other transport & 1.9694 & 0.4098 & 0.4334 & 0.0549 & 0.1024 & 0.0142 & 0.0063 \\
\hline Other manufacturing & 1.9640 & 0.5393 & 0.4373 & 0.0157 & 0.0057 & 0.0045 & 0.0089 \\
\hline Electricity, gas and water & 1.9841 & 0.7464 & 0.2312 & 0.0152 & 0.0071 & 0.0030 & 0.0048 \\
\hline Construction & 1.8613 & 0.5614 & 0.4169 & 0.0136 & 0.0055 & 0.0047 & 0.0171 \\
\hline Wholesale and retail trade & 1.5668 & 0.6364 & 0.3465 & 0.0083 & 0.0068 & 0.0032 & 0.0106 \\
\hline Hotels and restaurants & 2.1765 & 0.8538 & 0.1246 & 0.0189 & 0.0043 & 0.0020 & 0.0339 \\
\hline Transport, storage and communication & 2.1363 & 0.7701 & 0.2154 & 0.0101 & 0.0038 & 0.0025 & 0.0112 \\
\hline $\begin{array}{l}\text { Finance, insurance, real estate and } \\
\text { business services }\end{array}$ & 1.8367 & 0.8174 & 0.1738 & 0.0052 & 0.0025 & 0.0019 & 0.0075 \\
\hline Other services & 2.0703 & 0.7534 & 0.1722 & 0.0291 & 0.0449 & 0.0040 & 0.0475 \\
\hline Government services & 1.7431 & 0.7579 & 0.2256 & 0.0154 & 0.0021 & 0.0013 & 0.0247 \\
\hline
\end{tabular}

Note: Emp* = Employment

Source: Input-output table of West Malaysia, 2005

\section{CONCLUSIONS AND RECOMMENDATIONS}

The present paper examines the contribution of various sectors in West Malaysia by using regional input-output table for West Malaysia in 2005 basic year. The result shows that the productive sectors in West Malaysia recorded RM1,396,475 million (61 per cent) and the rest of the output was contributed by the unproductive sectors such as households and government consumption. In the same manner, the regional input-output table for West Malaysia also shows the total transactions between the productive sectors in this economy which was recorded at RM632,429 million. In 2005, the manufacturing, the electronics and non-electronics sector emerged as the main contributor to West Malaysia's output, generating an output amounting to RM346,073 million. The next largest sector was the finance, insurance, real estate and business services sector with output of RM194,332 million, followed by the wholesale and retail trade sector with output of RM160,198 million. For the 
linkages analysis, West Malaysia recorded eight key sectors (petroleum products; electronics and non-electronics; other manufacturing; electricity, gas and water; wholesale, and retail trade; transport, storage, and communication; finance, insurance, real estate and business services; and other services). Lastly, through analysis of the multipliers using the single region model, the petroleum products; electronics and non-electronics; motor vehicles and other transport; and other manufacturing sectors; were among the sectors with high multiplier values in West Malaysia. Additional units in final demand for these sectors would create high values of output, value added, import, domestic tax, import duties and employment in these regions. In summary, petroleum products, electronics and non-electronics, and motor vehicles and other transport and other manufacturing sectors among the main sectors that contributed to the West Malaysia's economy through the output generation, linkages analysis and multiplier analysis.

The significant economic growth for West Malaysia has largely been due to the achievements of the non-resource-based sectors (especially electronics and non-electronics). The roles of electronics and non-electronics as major sector in the economic growth for West Malaysia can be seen from their increasing shares in the GDP and total export. However, for planning purposes, the large dependency for economic growth on the electronics and non-electronics sector for West Malaysia need regional input-output table. The construction of this table is important in understanding the economic structures of West Malaysia and determining the contribution of each sector to the economy. Therefore, as a policy recommendation especially for planning purposes, the policymakers need to ensure that the non-resource-based sectors especially petroleum products, electronics and nonelectronics, and motor vehicles and other transport and other manufacturing sectors, record increasing efficiency in order to develop greater and stronger linkages with the economic activities in this region for future development. This can be done by integrating all the related economic activities into these sectors.

\section{Corresponding Author}

Mohd Khairul Hisyam Hassan

Faculty of Economics and Business, Universiti Malaysia Sarawak (UNIMAS)

Email: hmkhisyam@unimas.my

\section{REFERENCES}

Bolton, R. E., Jackson, R. W., and West, G. R. (1990). The Construction and Use of Regional InputOutput Models: Editors' Introduction to the Special Issue. International Regional Science Review, 13: 1-7.

Brucker, S. M., Hastings, S. E., and Latham III, W. R. (1990). The Variation of Estimated Impacts form Five Regional Input-Output Models. International Regional Science Review, 13(1\&2): 119-139.

Emerson, M. J. (1989). Regional Structural Change: a Comparison of Two Input-Output Models. SocioEconomic Planning Sciences, 23(5): 241-249.

Flegg, A. T., and Tohmo, T. (2010). Regional Input-Output Tables and the FLQ Formula: a Case Study of Finland. Bristol: 1-49. 
INTERNATIONAL JOURNAL OF ACADEMIC RESEARCH IN BUSINESS AND SOCIAL SCIENCES

Vol. 9, No. 1, Jan, 2019, E-ISSN: 2222-6990 ㄷ 2019 HRMARS

Flegg, A. T., and Tohmo, T. (2018). The Regionalization of National Input-Output Tables: A Study of South Korean Regions. Papers in Regional Science:1-20.

Hassan, M. K. H., Noor, Z. M., Ismail, N. W., Radam, A., and Rashid, Z. A. (2017). The Regional InputOutput Model for East Malaysia Region: Construction and Application. International Journal of Academic Research in Business and Social Sciences, 7(12): 712-731.

Hewings, G. J. D., and Jensen, R. C. (1988). Emerging Challenges in Regional Input-Output Analysis. Annals of Regional Science, 22: 43-53.

Jensen, R. C., and West, G. R. (1980). The Effects of Relative Coefficient Size on Input-Output Multipliers. Environment and Planning A, 12: 659-670.

Jensen, R. C., West, G. R., and Hewings, G. J. D. (1988). The Study of Regional Economic Structure using Input-Output Tables. Regional Studies, 22(3): 209-220.

Malaysia, Department of Statistics (2000). Report on Household Expenditure Survey 1998/99. Percetakan Nasional Malaysia Berhad: Kuala Lumpur.

Malaysia, Department of Statistics (2004). Annual National Product and Expenditure Accounts 1987-2003. Percetakan Nasional Malaysia Berhad: Kuala Lumpur.

Malaysia, Department of Statistics (2005). Input-Output Tables. Percetakan Nasional Malaysia Berhad: Kuala Lumpur.

Malaysia, Department of Statistics (unpublished). Annual National Product and Expenditure Accounts Sabah \& Sarawak 1987-2003.

Malaysia, Economic Report, various issues, Ministry of Finance.

Malaysia, External Trade Statistics, Malaysia, various issues, Department of Statistics.

Malaysia, External Trade Statistics, Sabah, various issues, Department of Statistics.

Malaysia, External Trade Statistics, Sarawak, various issues, Department of Statistics.

Malaysia, Yearbook of Statistics, Malaysia, various issues, Department of Statistics.

Malaysia, Yearbook of Statistics, Sabah, various issues, Department of Statistics.

Malaysia, Yearbook of Statistics, Sarawak, various issues, Department of Statistics.

Malaysia, Census of Manufacturing Industries, various issues, Department of Statistics.

Rasmussen, P. N. (1956). Studies in Intersectoral Relations. North-Holland, Amsterdam.

Richardson, H. W. (1972). Input-Output and Regional Economics. Halsted Press, New York. 